Ігор Коваль, Андрій Ковальчук, Андрій Петренко

\title{
АНАЛІЗ ПСИХОЛОГІЧНИХ ЯКОСТЕЙ СПОРТСМЕНІВ ПОЖЕЖНО-ПРИКЛАДНОГО СПОРТУ В ЗМАГАЛЬНІЙ ДІЯЛЬНОСТІ
}

Ще з середини минулого століття професійну діяльність спортсменів науковці та практики називають екстремальною, розуміючи при цьому, що досягнення високих результатів, першість у змаганнях вимагають від них надмірних зусиль і максимального «викладення». Нині, без сумніву, в спортсменів спостерігається надмірна не лише фізична, а й нервовопсихологічна напруга, особливо це спостерігається у представників пожежно-прикладного спорту (ППС), оскільки вони тренуються в умовах, наближених до стресогенних. Необхідно зазначити, що спортивна діяльність представників пожежно-прикладного спорту проходить у постійних екстремальних умовах, які травмують не лише фізично, а й психологічно, вводячи індивідів у депресію, апатію, конфлікти чи навіть тривожність.

Науковці інтенсивно досліджують форми та напрями організації занять із фізичного виховання [6], вплив екстремальних умов на спортсменів [1; 10]; розробляють методи і засоби профілактики негативного впливу незвичайних умов на особистість [3]; вивчають специфіку управління стресом під час змагань [4]. Водночас М. Самойлов наголошує на тому, що для кожного конкретного виду спорту притаманні стресогенні чинники, які впливають на психологічний стан індивіда [10]. У галузі психології спорту цікавими є дослідження психологічних аспектів спортивного відбору команд В. Волкова [2], психологічні особливості готовності спортсменів Ф. Генова [5]. Однак нині наука потребує досліджень у галузі пожежно-прикладного спорту щодо впливу екстремальних умов на формування особистості спортсменів.

Мета дослідження - визначити психологічні якості спортсменів пожежно-прикладного спорту, необхідні для змагальної діяльності.

Для кожної людини здоров'я є найважливішою основою повноцінного, гармонійного, усебічного розвитку особистості, компонентом якого виступає фізичне виховання. Його мета полягає у загартуванні людського організму,

(c) Ігор Коваль, Андрій Ковальчук, Андрій Петренко, 2019 
зміцненні здоров'я, підтримці та покращенні фізіологічного стану, тобто формуванні фізично здорової людини. Тому одним із провідних завдань соціуму є сприяння у вихованні фізично здорової нації. Відповідно до даних епідеміологів, здоровими вважаються 27\% дітей дошкільного віку, гармонійно розвинутими - 65\% дітей і 60\% підлітків [8]. Це свідчить про те, що спортивно-масова діяльність у навчальних закладах повинна складатись відповідно до індивідуальних і колективних особливостей фізіології людини.

Розглядаючи заняття з фізичного виховання в освітніх закладах Державної служби України з надзвичайних ситуацій (ДСНС України), наголосимо на високому рівні небезпеки при виконанні майбутніх службових обов'язків, оскільки, починаючи з другого курсу, курсанти і студенти проходять практики в пожежно-рятувальних підрозділах України, беручи безпосередню участь у забезпеченні життєдіяльності населення (рятування людей і цінностей, ліквідація наслідків надзвичайних ситуацій). Зважаючи на це, на заняттях із фізичного виховання у закладах освіти необхідно дбати про покращення здоров'я та компетентну фахову підготовку майбутніх рятувальників до діяльності в умовах ризику.

Фізичне виховання рятувальників має на меті використання екстремальних видів спорту, які характеризуються значними фізичними навантаженнями, психологічною напругою, викидом адреналіну. Одним із таких є пожежно-прикладний спорт, який супроводжується постійною небезпекою, можливими травмуваннями, оскільки складається 3 таких вправ: подолання 100метрової смуги $з$ перешкодами; підіймання по штурмовій драбині на 4 поверх навчальної башти; підіймання по висувній драбині на 3 поверх навчальної башти; двоборство (складається 3 двох вправ: подолання 100-метрової смуги 3 перешкодами та підіймання по штурмовій драбині на 4 поверх навчальної башти); пожежна естафета 4х100 м; бойове розгортання [8, с. 5].

Методологічною основою пожежно-прикладного спорту є системний підхід, оскільки зазначені вище вправи перевантажують функціональні системи організму, що вимагає від спортсмена поступової підготовки до виконання кожного нормативу, оскільки вони відрізняються між собою та вимагають різноплановості тренувального процесу. Також цей вид спорту є невід’ємною складовою фізичного виховання рятувальників служби цивільного захисту, сприяючи не лише фізичному розвитку особистості, а й формуванню дисциплінованості, відповідальності, впевненості, цілеспрямованості та вмінню швидкодії, що зумовлюється високим рівнем психоемоційного напруження.

Упродовж 2015-2016 рр. ми досліджували ефективність навчальнотренувального процесу в циклічних видах спорту при впровадженні про- 
грамної розробки «Андроїд» «GPS Sports Tracker Running Cycling» [3], тому в цій статті розглянемо психологічну складову особистості.

У дослідженні взяли участь курсанти Львівського державного університету безпеки життєдіяльності, які не лише є діючими спортсменами області, а й входять до складу збірної команди України з пожежно-прикладного спорту, вік котрих - 17-22 роки. Усі спортсмени тренувалися за програмами, складеними й обговореними на засіданні кафедри спеціально-рятувальної підготовки та фізичного виховання Львівського державного університету безпеки життєдіяльності.

Основою тренувального процесу є засади гуманності та демократії, що сприяє різнобічності форм і методів фізичного виховання з боку не лише викладачів, а й спортсменів. Це сприяє усвідомленій участі всіх учасників тренувань у вдосконаленні умов підготовки.

Вивчаючи навчально-тренувальний процес, ми склали анкету визначення психологічних чинників становлення спортсменів у пожежно-прикладному спорті. Загалом вибірка склала 20 осіб чоловічої статі віком від 17 до 22 років, які повинні у кожному запитанні обрати по три відповіді. Розглянемо результати анкетування детальніше.

На перше запитання «Які чинники впливають на результати підготовленості спортсменів?» отримано такі результати (див. рис. 1):

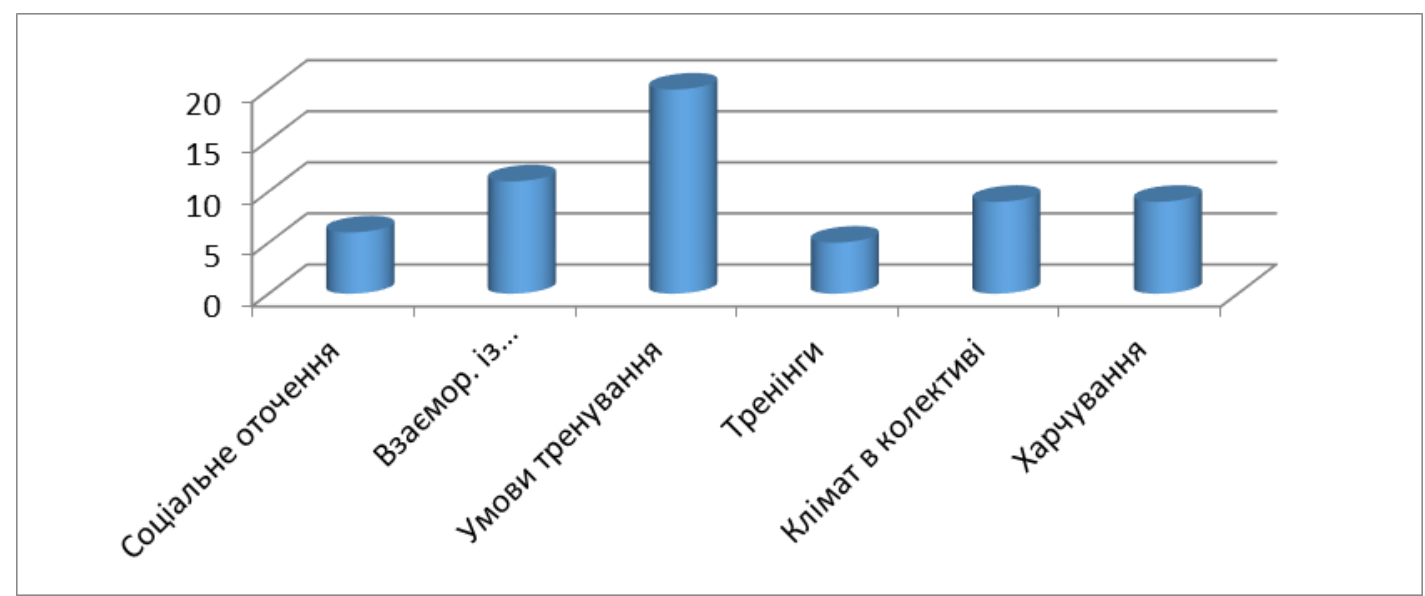

\section{Рисунок 1 - Чинники впливу на підготовленість спортсменів із ППС}

Із рис. 1 бачимо, що, на думку респондентів, умови тренування (матеріальна база) (100\%), взаєморозуміння 3 тренером (55\%), соціальнопсихологічний клімат у колективі (45\%), харчування (45\%), соціальне оточення (30\%), тренінги (25\%) чинять максимальний вплив на результати підготовленості спортсменів у пожежно-прикладному спорті.

На запитання «Які психологічні якості характеру необхідно розвивати для досягнення високих показників у спорті?» отримано такі результати (див. рис. 2): 


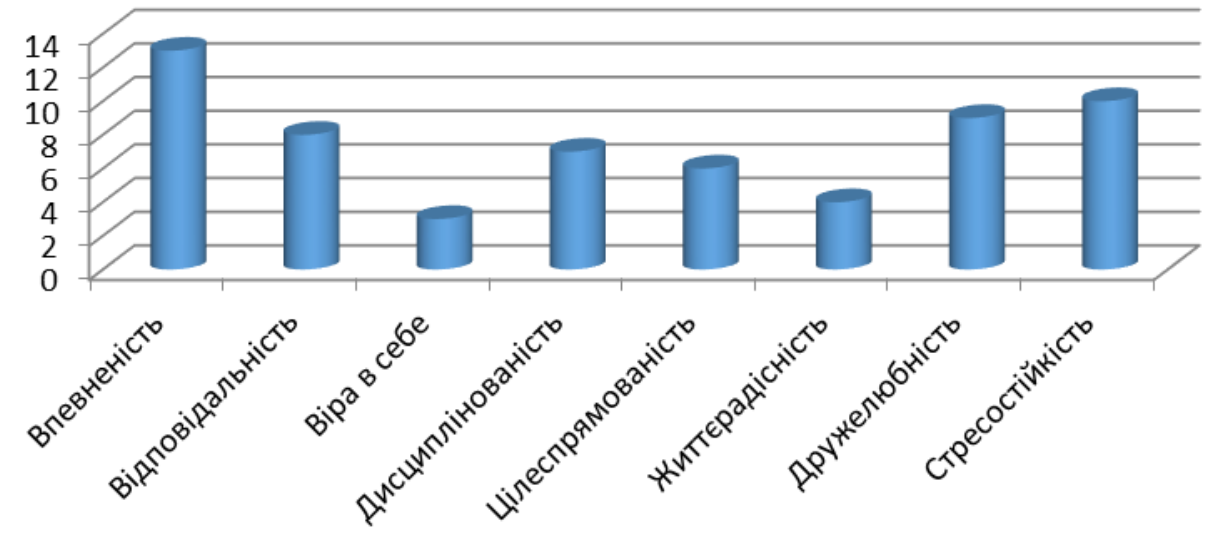

\section{Рисунок 2 - Якості характеру спортсменів із ППС}

Аналіз результатів відповідей на друге питання показує, що такі риси характеру, як упевненість (65\%), стресостійкість (50\%), дружелюбність (45\%), відповідальність (40\%), дисциплінованість (35\%), цілеспрямованість (30\%), життєрадісність (20\%) та віра в себе $(15 \%)$, характерні для спортсменів пожежно-прикладного спорту та, своєю чергою, потребують формування і розвитку.

Відповідаючи на питання «Які, на Вашу думку, головні ознаки підготовленості спортсменів пожежно-прикладного спорту до змагань?» опитані виокремили такі ознаки (див. рис. 3):

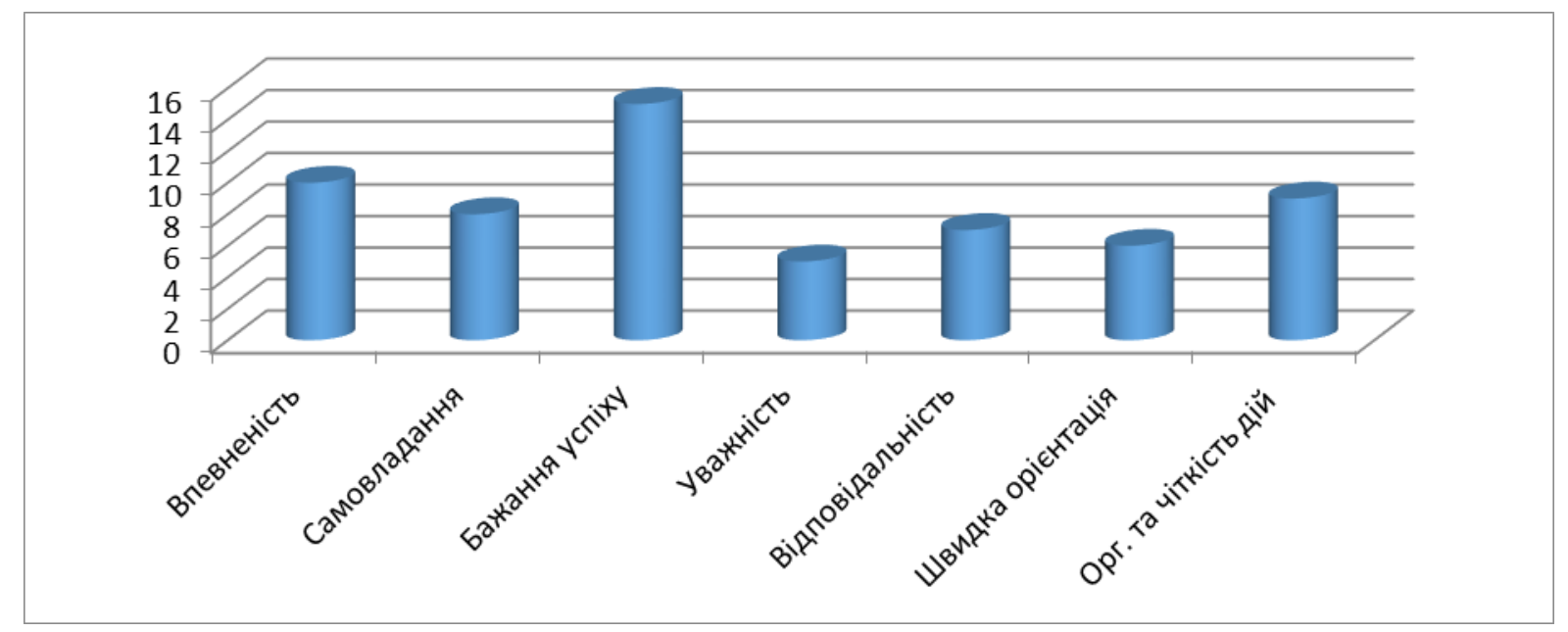

\section{Рисунок 3 - Ознаки підготовленості спортсменів із ППС}

Результати анкетування свідчать, що бажання успіху (75\%), впевненість у собі та у своїх діях (50\%), організованість і чіткість дій (45\%), самовладання (40\%), відповідальність (35\%), швидка орієнтація (30\%), уважність (25\%) є ознаками підготовленості спортсменів пожежно-прикладного спорту до змагань.

Узагальнивши відповіді респондентів на запитання відкритого типу «Які заходи необхідно впроваджувати в навчально-тренувальний про- 
цес підготовки спортсменів?», ми виокремили такі заходи: тренування за допомогою програмної розробки «Андроїд» «GPS Sports Tracker Running Cycling» (100\%), психологічні тренінги (65\%), здорове та вітамінізоване харчування (50\%), здоровий сон (35\%), вивчення спортивних нормативів і правил змагань (30\%), відеоперегляди змагань (20\%).

Підсумовуючи результати анкетування, зазначимо, що при розробці програм підготовки спортсменів пожежно-прикладного спорту необхідно не лише звертати увагу на інноваційно-технологічні розробки, а й робити акцент на морально-психологічній складовій, яка, як бачимо з вищеподаних гістограм, впливає на результат спортивної діяльності особистості. Зважаючи на результати проведеного дослідження, у змагальній діяльності необхідно: ретельно вивчати організаційні проблеми (визначення лідерів, їх навчання і виховання, постійна оцінка результативності, стимулювання спортсменів), забезпечуючи необхідними засобами й матеріалами; цілеспрямовано формувати колектив; постійно аналізувати негативні соціально-психологічні явища, які виникають між спортсменами. Також, підбираючи форми і методи тренувального процесу, викладачі повинні враховувати вікові й індивідуальні особливості спортсменів, їх задатки й інтереси, тобто «щоб виховати людину в усіх розуміннях, треба її знати у всіх відношеннях» [9].

Таким чином, одержані результати актуальної наукової проблеми дослідження психологічних якостей спортсменів пожежно-прикладного спорту засвідчують, що ії вирішення потребує розуміння й особливої психологічної підготовки, яка повинна стати невід'ємною складовою професіоналізму сучасного спортсмена. Успішність виступів у змаганнях зумовлена не лише рівнем фізичної підготовленості, а й здатністю переносити нервовопсихологічні навантаження, адже цей вид спорту супроводжується постійними стресовими ситуаціями. Перспективи подальших досліджень полягають у тому, щоб розробити, експериментально перевірити та впровадити в тренувальний процес пожежно-прикладного спорту комплекс тренінгових занять, які розвиватимуть упевненість, цілеспрямованість, відповідальність, наполегливість, а головне - навчать методам автогенного тренування.

\section{Jimepamypa:}

1. Бесчастный В. Н. Психотехнологии в подготовке работников ОВД для действий в экстремальных ситуациях. Психологические технологии в экстремальных видах деятельности : материалы междунар. науч.-практ. конф. 2223.03.2008 г. Донецк : ДЮИ ЛГУВД, 2008. С. 41-45.

2. Волков В. М. Восстановительные процессы в спорте. М. : Физкультура и спорт, 1987. $143 \mathrm{c}$.

3. Воронова В. І. Психологія спорту : навч. посіб. для студ. вищ. навч. закл. К. : Олімп. л-ра, 2007. 298 с. 
4. Вяткин Б. А. Управление психологическим стрессом в спортивных соревнованиях. М. : Физкультура и спорт, 1991. 112 с.

5. Генов Ф. Ю. Психологические особенности мобилизационной готовности спортсмена. М. : Физкультура и спорт, 1989. 201 с.

6. Коваль I. С., Ковальчук А. М., Петренко А. М. Упровадження програмних засобів у навчально-тренувальний процес циклічних видів спорту. Вісник Львівського державного університету безпеки життєдіяльності. 2016. № 13. С. 191-195.

7. Основи педагогіки. Психологія та педагогіка : Матеріали для Нової української школи. 1 клас - планування, розробки уроків, дидактичні та методичні матеріали, підручники та зошити. URL: https://subject.com.ua/psychology/psyho pedagog/119.html.

8. Правила змагань з пожежно-прикладного спорту. К., 2011.96 с.

9. Психология и современный спорт: сборник научных работ психологов спорта социалистических стран. М. : Физкультура и спорт, 1983. Вып. 1. 324 с.

10.Самойлов М. Г. Психологічна стійкість, як основний чинник подолання негативного впливу на психіку спортсменів експериментальних ситуацій. Слобожанський науково-спортивний вісник. 2010. № 1. С. 146-148.

11. Чурсов М. В. Концептуальна антиципація екстремальних ситуацій (соціальнофілософський та методологічний аспекти) : автореф. дис. ... канд. філос. наук : спец. 09.00.03 «Соціальна філософія і філософія історії». О., 2000. 19 с.

\section{References (transliterated and translated):}

1. Beschastnyiy V. N. Psihotehnologii v podgotovke rabotnikov OVD dlia deystviy v ekstremalnyih situatsiyah (Psycho-technologies while training workers of internal affairs departments for actions in extreme situations) Psihologicheskie tehnologii v ekstremalnyih vidah deyatelnosti : materialyi mezhdunar. nauch.-prakt. konf. 22-23.03.2008 g. (Psychological technologies in extreme activities : Proceedings of International scientific and practical conf. 22-23.03.2008). Donetsk : DYuI LGUVD, 2008. P. 41-45. (in Russian).

2. Volkov V. M. Vosstanovitelnyie protsessyi v sporte (Reconstructive processes in sports). Moscow : Fizkultura i sport (Physical Culture and Sport), 1987. 143 p. (in Russian).

3. Voronova V. I. Psykholohiya sportu : navch. posib. dlia stud. vyshch. navch. zakl. (Psychology of Sport : Tutorial for higher school students). Kyiv : Olimp. 1-ra, 2007. 298 p. (in Ukrainian).

4. Vyatkin B. A. Upravlenie psihologicheskim stressom v sportivnyih sorevnovaniyah (Management of psychological stress in sports competitions). Moscow : Physical Education and Sport, 1991. 112 p. (in Russian).

5. Genov F. Yu. Psihologicheskie osobennosti mobilizatsionnoy gotovnosti sportsmena (Psychological features of the mobilization readiness of an athlete). Moscow : Physical Education and Sport, 1989. 201 p. (in Russian).

6. Koval I. S., Kovalchuk A. M., Petrenko A. M. Uprovadzhennia prohramnykh zasobiv u navchalno-trenuvalnyi protses tsyklichnykh vydiv sportu (Introduction of software tools in the training process of cyclic sports). Visnyk Lvivskoho derzhavnoho universitetu bezpeky zhyttediyalnosti (Visnyk of Lviv State University of Life Safety). 2016. No 13. P. 191-195. (in Ukrainian).

7. Osnovy pedahohiky. Psykholohiia ta pedahohika : Materialy dlia Novoi ukrainskoi shkoly. 1 klas - planuvannia, rozrobky urokiv, dydaktychni ta 
metodychni materialy, pidruchnyky ta zoshyty (Fundamentals of pedagogy. Psychology and Pedagogy : Materials for the New Ukrainian School. Class 1 - Planning, plans of lessons, didactic and teaching materials, textbooks and notebooks). URL: https://subject.com.ua/psychology/psyho_pedagog/119.html. (in Ukrainian).

8. Pravyla zmahan z pozhezhno-prykladnoho sportu (Rules of competitions in fire and applied sports). Kyiv, 2011.96 p. (in Ukrainian).

9. Psihologiya i sovremennyiy sport: sbornik nauchnyih rabot psihologov sporta sotsialisticheskih stran (Psychology and modern sport: Collected works of sports psychologists from socialist countries). Moscow : Physical Education and Sport, 1983. Issue 1. 324 p. (in Russian).

10. Samoilov M. H. Psykholohichna stiykist, yak osnovnyi chynnyk podolannia nehatyvnoho vplyvu na psykhiku sportsmeniv eksperymentalnykh situatsiy (Psychological stability as the main factor in overcoming the negative impact on the psyche of athletes in experimental situations). Slobozhanskyi naukovo-sportyvnyi visnyk (Slobozhansky Scientific and Sport Bulletin). 2010. No 1. P. 146-148. (in Ukrainian).

11.Chursov M. V. Kontseptualna antytsypatsiya ekstremalnykh sytuatsiy (sotsialnofilosofskyi ta metodolohichnyi aspekty) : avtoref. dys. kand. filos. nauk : spets. 09.00.03 «Sotsialna filosofiya i filosofiya istorii» (Conceptual anticipation of extreme situations (socio-philosophical and methodological aspects) : Author's abstract of $\mathrm{PhD}$ thesis in Philosophy : specialty 09.00.03 «Social Philosophy and Philosophy of History»).Odesa, 2000. 19 p. (in Ukrainian).

Стаття надійшла до редакції 10.01.2019

\section{I. Коваль, А. Ковальчук, А. Петренко} Аналіз психологічних якостей спортсменів пожежно-прикладного спорту в змагальній діяльності

У статті здійснено поглиблений аналіз підготовки спортсменів пожежно-прикладного спорту. Досліджено та систематизовано ключові позиції вчених щодо форм і напрямів організації занять із фізичного виховання. Розроблено авторську анкету визначення психологічних чинників становлення спортсменів у пожежно-прикладному спорті, за її допомогою проведено анкетування діючих спортсменів Львівського державного університету безпеки життєдіяльності. Автори роблять висновок, що при розробці програм підготовки спортсменів пожежно-прикладного спорту необхідно не лише звертати увагу на інноваційно-технологічні розробки, а й робити акцент на морально-психологічній складовій, яка впливає на результат спортивної діяльності особистості. Тому в змагальній діяльності необхідно: ретельно вивчати організаційні проблеми, забезпечуючи необхідними засобами й матеріалами; цілеспрямовано формувати колектив; постійно аналізувати негативні соціально-психологічні явища, які виникають між спортсменами. Одержані авторами результати актуальної наукової проблеми дослідження психологічних якостей спортсменів пожеж- 
но-прикладного спорту засвідчують, що їі вирішення потребує розуміння й особливої психологічної підготовки, яка повинна стати невід'ємною складовою професіоналізму сучасного спортсмена. Успішність виступів у змаганнях зумовлена не лише рівнем фізичної підготовленості, а й здатністю переносити нервово-психологічні навантаження, адже цей вид спорту супроводжується постійними стресовими ситуаціями.

Ключові слова: спортсмени, пожежно-прикладний спорт, навчально-тренувальний процес, анкета визначення психологічних чинників.

\section{Koval, A. Kovalchuk, A. Petrenko Analysis of Psychological Qualities of Athletes of Fire-Applied Sports in Competitive Activities}

The article provides an in-depth analysis of the training of athletes in fireapplied sports. The key positions of scientists concerning the forms and directions of organization of physical education classes are researched and systematized. The author's questionnaire has been developed to determine the psychological factors of the development of athletes in fire-applied sports, and with its help a survey of active athletes of Lviv State University of Life Safety has been conducted. The authors conclude that the development of training programs for athletes in the field of fire-applied sport requires not only paying attention to innovation and technological developments, but also focusing on the moral and psychological component, which affects the outcome of the individual's sports activities. Therefore, in competitive activities it is necessary: carefully to study the organizational problems, providing the necessary means and materials; purposefully to form a team; and constantly to analyze the negative sociopsychological phenomena that arise between athletes. The results of the topical scientific problem of studying the psychological qualities of athletes in fireapplied sports obtained by the authors indicate that its solution requires an understanding and special psychological training, which should become an integral part of a modern athlete's professionalism. The success in competitions is due not only to the level of physical fitness, but also the ability to endure neuropsychological stress, as this sport is accompanied by constant stressful situations.

Key words: athletes, fire-applied sports, educational process, questionnaire for determination of psychological factors.

Рецензент - кандидат психологічних наук, доцент В. І. Слободяник 